\title{
The Economics of an Early Nineteenth-Century Toronto Newspaper Shop
}

\author{
Julie Stabile
}

In the first half of the nineteenth century, what were the economic circumstances of a successful Toronto newspaper shop? What were the typical expenses of such a shop and what kind of revenue could a proprietor expect from such an undertaking? These are difficult questions because, unfortunately, account books, ledgers, or a set of printers' papers for Toronto newspaper proprietors either have not survived or are incomplete. A portrait of the economic context must be pieced together from scattered records for Toronto offices and from information in the newspapers themselves, and then compared to documentation for shops in other towns. In order to conduct this analysis I created a hypothetical account book for a typical Toronto shop in the first half of the nineteenth century. In the discussion of this account book, I will first explore the expenses - equipment, supplies, and labour for a typical year, and then outline the revenue for a shop proprietor.

From 1798 to 1845 , thirty-two newspapers were launched in Toronto. Seventeen of these survived less than five years: ten endured less than one year, another four less than two years and another three less than five years. Of the 15 newspaper shops that functioned for five or more years, a number suffered financial difficulties. Although a newspaper enterprise was a serious business in Toronto, it was also a precarious undertaking, as explained by a contemporary Montreal journalist:

Any individual is at liberty to commence a publication when and where he pleases; but it is one thing to issue a prospectus and another to establish a journal, particularly in a district where there are many existing....The risk is great and the chances are much against a new publication ... for a considerable outlay is certain, while a return of that outlay is equally uncertain. ${ }^{2}$

I Julie Stabile works at the Archives of Ontario. She studied early Upper Canadian newspapers for research on her doctoral dissertation, completed in 2002.

2 Montreal Herald as quoted in the Courier of $U_{p p e r}$ Canada 13 Oct. I832. 


\section{Expenses}

According to the garrulous William Lyon Mackenzie,

a newspaper [was] truly a very costly undertaking. Type, presses, cases, ink, paper, and many other perishable materials, rents, fuels, postages, duties, freight, carriage, clerkhire, journeymen their wages, apprentices their clothing and maintenance, smiths' work, carpenters' work - these are some of the items always to be provided for - as also the editor, and the foreman or manager of the concern of the office, with a reporter occasionally. ${ }^{3}$

Most of the evidence suggests that approximately $\mathfrak{f}_{750}$ was required to establish a newspaper shop in early Toronto. Historians have claimed that the $£ 625$ awarded Mackenzie in 1826 in compensation for the vandalism to his office was enough to pay off his creditors and re-establish his business. In order for this amount to be sufficient to cover all costs, some equipment must have survived the attack, because when Mackenzie was selling this shop in 1833 , he stated that all the furnishings had initially cost him $£_{750} .^{4}$ After having been dismissed as King's Printer, Charles Fothergill sought advice from Attorney General John Beverley Robinson on how to raise $£ 500$ or $£ 600$ to establish a press in Port Hope. ${ }^{5}$ Fothergill possibly already had some capital and thus asked for an amount less than $\mathfrak{E}_{750}$. In I829 the conference for the Wesleyan Methodist Church authorized $\$ 700$ to purchase all the apparatus for a printing shop and a sum of $\$ 2050$ to meet the annual expenses of conducting a newspaper; ${ }^{6}$ the total expense again amounted to approximately $\mathfrak{5}_{750} .^{7}$ In order to persuade Peter Brown to establish a newspaper supporting the Free

3 Colonial Advocate in Nov. I830.

4 Frederick Armstrong and Ronald Stagg, "Mackenzie, William Lyon," in Dictionary of Canadian Biography, IX, ed. George Brown, David Hayne and Francess G. Halpenny (Toronto: U of Toronto P, 1976), 497; and Correspondent and Advocate 15 Jan. 1835 .

5 Fothergill to Beverley Robinson, March 1829, Volume 2: Letters 1829-1837, Charles Fothergill Papers, MS Collection I40, Thomas Fisher Rare Book Library, University of Toronto.

6 Minutes of the Conference at Ancaster, 26 Aug. to 4 Sept. 1829, Wesleyan Methodist Church in Canada, Fonds 513 83.06IC, United Church of Canada/ Victoria University Archives, Toronto.

7 My calculations for currency equivalents are based on one Halifax dollar being equal to approximately $5 \mathrm{~s}$, as indicated in Douglas McCalla's Planting the Province: The Economic History of Upper Canada, 1784-I870 (Toronto: U of Toronto P, 1993). 
Kirk cause in 1843 , a group of Scotsmen put up a bond of $\$ 2500$, or almost $£ 700$. Once Peter Brown’s Banner was successfully launched, four investors provided his son, George Brown, with £250 of immediate capital to publish the reform newspaper, the Globe. Later Robert Baldwin furnished the younger Brown with another $\mathfrak{E}_{50}$ for additional type and printing stock. ${ }^{8}$ Because the Globe used the same premises and equipment as the Banner, the initial expenses were less than the stipulated $\mathfrak{E}_{750}$. In $18 \mathrm{I} 7$ after the Upper Canada Gazette office had been destroyed in the war, the printer ordered new type at a cost of $£ 25 \mathrm{I} 7 \mathrm{~s} 6 \mathrm{~d} .{ }^{9}$ If the Globe and Banner were printed on the same presses, the amount provided to George Brown -£250 - would have covered the costs for an entire new set of type.

If proprietors lacked financial backers they raised the initial capital in several ways. Fothergill was willing to guarantee his loan with a mortgage on his farm. ${ }^{\mathrm{IO}}$ Not wanting to incur such a debt, John Carey of the Observer and Francis Collins of the Canadian Freeman tried to get subscriptions for the required capital. ${ }^{\text {II }}$ To finance the Christian Guardian the directors of the Wesleyan Methodist conference sold shares of stock in the printing establishment. ${ }^{\mathrm{I}}$

After expending the initial capital to establish a printing shop, proprietors faced recurring costs. Frequently, additional presses or an improved press needed to be purchased for more efficient and better quality output. With constant use, type was quickly worn out, and according to Mackenzie, had to be renewed annually to maintain quality and readership; ${ }^{13}$ in fact, the government allowed Robert Stanton, the King's Printer, £5o a year for new type. ${ }^{\mathrm{I}}$ Although the costs for new presses and type varied from office to office, the accounts of the Christian Guardian shop provide a typical

8 J.M.S. Careless, Brown of the Globe, vol.I, The Voice of Upper Canada I818-1859 (Toronto: Macmillan, 1959), 23-45.

9 Warrant for payment, York, 27 Feb. 1817, Canadian Documents, Manuscript Collection 13I, Box 2, Thomas Fisher Rare Book Library, University of Toronto.

Io Fothergill to Beverley Robinson, Mar. 1829, Charles Fothergill Papers.

II Upper Canada Gazette 6 Apr. 1820, containing the prospectus for the Observer; and Colonial Advocate i4 Apr. 1825, containing the prospectus for the Canadian Freeman.

12 Minutes of Conference at Ancaster, 26 Aug. to 4 Sept. 1829, Wesleyan Methodist Church in Canada.

I3 Colonial Advocate 3 June 1830.

I4 House of Assembly, "Detailed Accounts of the Government of Upper Canada for the year 1839," Appendix to the Journal of the House of Assembly of Upper Canada, $5^{\text {th }}$ Session of the $13^{\text {th }}$ Parliament, 1839-1840, Vol. I. 


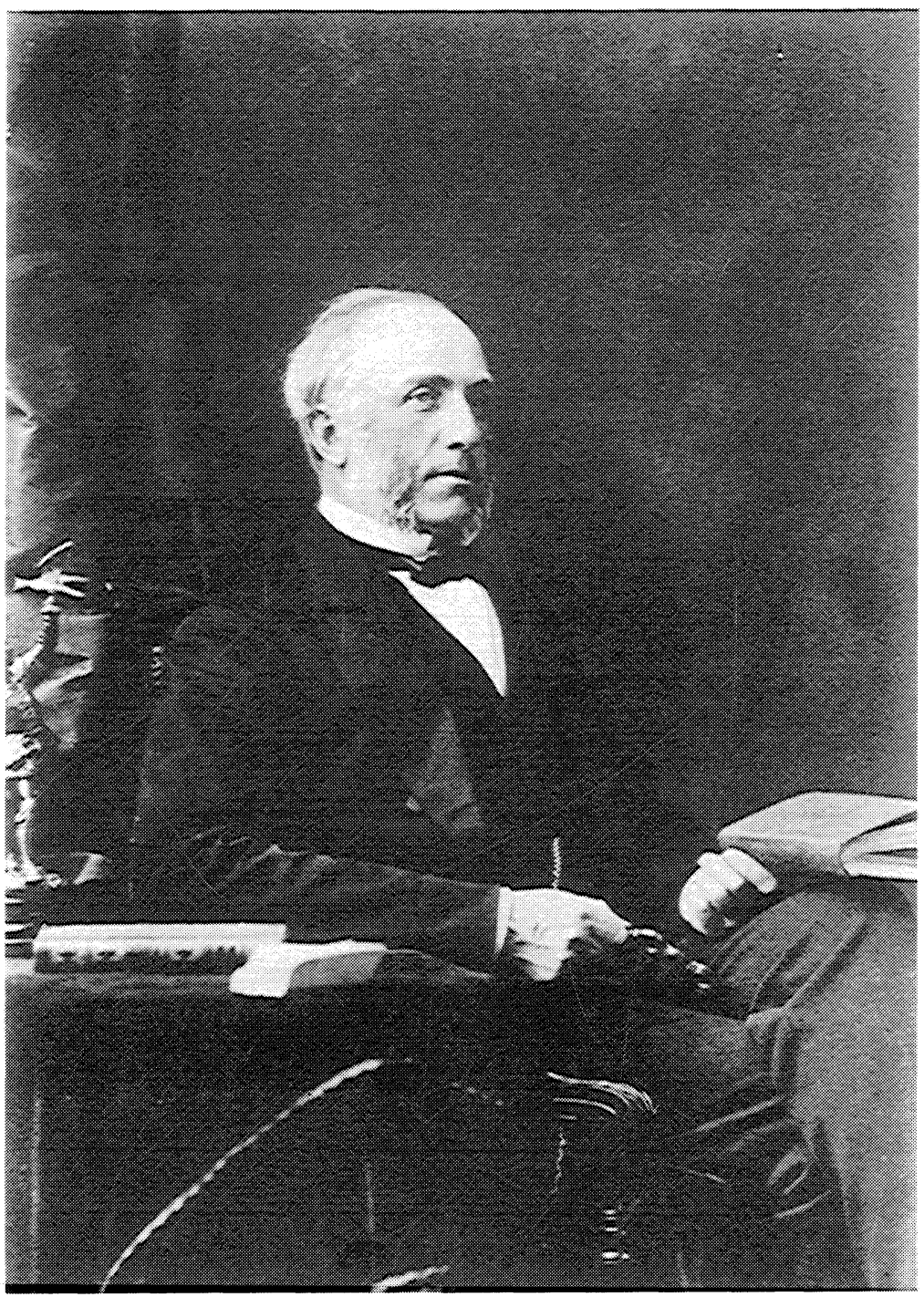

Figure I. The Honouorable George Brown, I880, proprietor and editor of The Globe. Reproduced from a negative held at the Archives of Ontario (S 34I). 


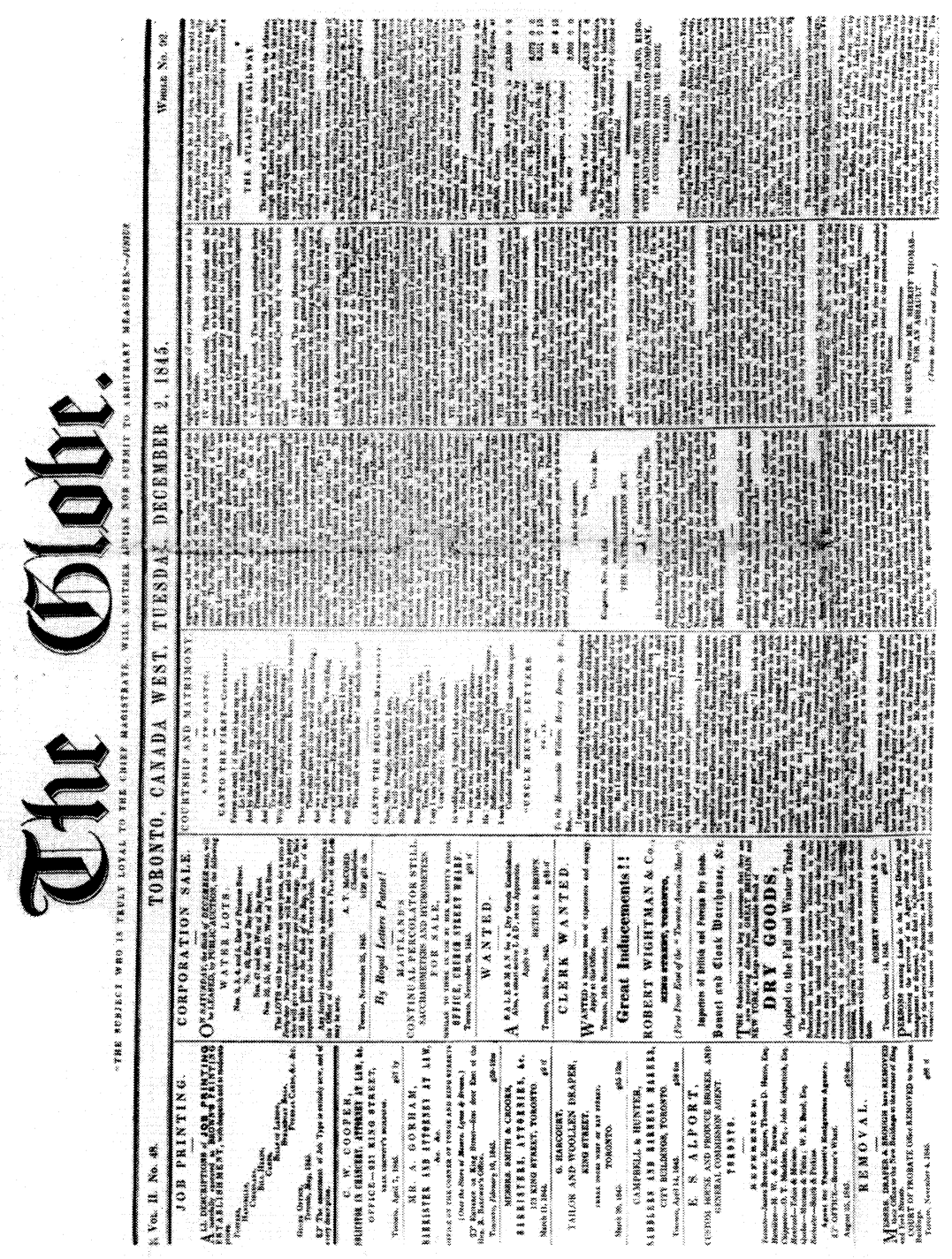

Figure 2. The Globe, 2 December 1845 . Reproduced from a copy held at the Metropolitan Toronto Reference Library, Baldwin Room. 
example. During its second year of operation in 1830 , this office purchased an additional press for £310. By 1836 the printing committee presented a very strong case for new and improved equipment; it explained that

the printing establishment is much restricted and injured in its operation for want of an additional printing press and a suitable quantity of type. For want of the former many profitable jobs have not infrequently of necessity to be refused; and for want of the latter it is found inconvenient to publish any works of importance in that workman-like manner of execution which is requisite to secure the respectability and permanency of the concern. It is supposed that the press and type will cost $£_{150 . . .}$ The committee recommends this purchase.

New type and office furniture costing $£_{73}$ were purchased again in I838. The total recorded costs for new equipment from 1830 to 1838 - that is, $\mathfrak{£}_{310}+£_{150}+£_{73}$ - equalled $£_{533}$ for eight years or $£_{66}$ a year. By 1844 the presses and type in this printing office had a total value of $£ 550$. In 1851 the directors thought it was expedient to suffer a deficit for the current year in order to purchase a new, much improved press: it was the first office in Toronto to purchase a steam- powered press, at a cost of $£ 550$. $^{\text {I5 }}$

Mackenzie also regularly purchased additional or improved equipment for his shop. Although he had bought a new cast-iron Smith press in 1825 , by March of the following year, he was entertaining the purchase of additional presses from George Bruce of New York: either "a standing press having a screw of $3 \mathrm{I} / 4$ inch diameter for \$150," or a smaller one for \$125. By I830 press design had undergone further improvements and again Mackenzie was considering updating his office. George Bruce suggested a new iron press built by Robert Hoe and Company or by Samuel Rust that would cost $\$ 230$, or a more modest but less efficient Ramage press for \$160. In addition to outlays for presses, in I827 Mackenzie was billed \$103.29 from George Bruce for a supply of type, leads, flowers, and ornaments. ${ }^{16}$ If he chose and purchased the more expensive

I5 The Reports of the Book and Printing Committee 1830-1851, Appendix to Annual Conference Minutes, I824-1854, Wesleyan Methodist Church in Canada, fonds 78-005C, Box I, United Church of Canada/Victoria University Archives. The information on equipment in Mackenzie's shop was obtained from the William Lyon Mackenzie Correspondence, Mackenzie-Lindsey Papers, Archives of Ontario and from Patricia Fleming "William Lyon Mackenzie as Printer, 1824-1837," The Devil's Artisan 6 (1981): 3-19. 
presses, Mackenzie's equipment expenses for the years I826 to I830 would have totalled $\$ 483$ - that is, $\$ 150+\$ 230+\$ 103-$ or an average of $£_{30}$ a year.

Although these calculations are based on incomplete evidence, they offer an approximate account of equipment costs and are fairly representative when compared to expenses of offices in other towns. Hugh Thomson's busy printing shop and newspaper office in Kingston had similar disbursements. In I831 Thomson spent approximately $\$ 360$ or about $£_{90}$ for type and another $£_{65}$ for a press, probably one of the superior iron presses recommended by George Bruce. This particular purchase of type must have been exceptionally large, for he spent a total of $£_{370}$ on type from I8I9 to 1833, which would equate to an annual expense of $£ 25$, a cost similar to that incurred by Mackenzie in $1827 .{ }^{17}$

By 1835 type could be purchased at comparable prices either at New York or Montreal, where the newly established Montreal Type Foundry claimed that "prices [were] the same as the United States." Old type could be exchanged for new, both in the province and across the border: the Montreal Type Foundry paid six pence a pound for old type and the New York firms paid nine cents a pound. ${ }^{18}$

Historians have repeatedly asserted that next to wages, paper was a printing shop's largest expense. ${ }^{19}$ Early Toronto newspapers provide evidence to support this claim. In 1829 the Christian Guardian office, which purchased paper both from the local paper maker, Eastwood and Skinner, and from Youngstown, New York, paid £52 to each supplier in addition to another $£_{14}$ in duties for the paper crossing the border. Because this office continued to order better quality paper from Youngstown, its costs for paper the following year amounted to $\$ 900$ ( $\left.£_{225}\right)$. By 1833 the Christian Guardian shop was spending $\$ 25$ a week on paper, and complained that the debt due Eastwood and Skinner had accumulated to an "enormous amount." The printing committee stated:

17 Upper Canada Herald Ledger, I830-1833, F4269, Archives of Ontario.

I8 Prices for New York are taken from John T. White's advertisement for the New York Type Foundry and Printer's Warehouse in the Morning Star and Toronto Transcript I8 May I84I; and those for Montreal from the Montreal Type Foundry's advertisement in the British Colonist 4 July I845.

19 See George Parker, The Beginnings of the Book Trade in Canada (Toronto: U of Toronto P, 1985), 49; and Lawrence C. Wroth, The Colonial Printer (1931; reprint, New York: Dover Publications, 1994), I51. 
It must be obvious that considerable embarrassment must arise to those in charge of the office from so great an amount of debt due for the principal working material. It is not only very disagreeable to the feelings of those concerned, but it is detrimental to the credit and interests of the establishment, as it in a great measure prevents the purchase of the materials to much better advantage from some other quarter, and causes a dependence upon the manufacturer. ${ }^{20}$

At the time this shop was probably using more paper than a typical office of that period because it had secured the public printing contracts from the House of Assembly. ${ }^{2 I}$ Mackenzie and Hugh Thompson, both of whom were job printers as well as newspaper publishers, spent from $\$ 8$ to $\$$ ro a week or about $£$ r3o a year on paper during the early I830s. ${ }^{22}$ These figures approximate the paper costs of the Christian Guardian office in 1829 , when it did not have large government contracts and are probably more representative of a typical shop.

A printing office also incurred expenses for rent, insurance, ink, and such contingencies as fuel, candles, wrapping paper, and twine. The cost of rent depended on the size and location of the shop. In the early I830s, rent for the Christian Guardian premises was between $£_{19}$ and $£_{2} 6$ a year, while during the same period, the rent paid by Hugh Thomson for the Upper Canada Herald office in Kingston was $£ 50$ annually. The rent allowance for Stanton, King's Printer, was $£ 40$ a year. ${ }^{23}$ Perhaps the Kingston premises and those for the Upper Canada Gazette were large, or those for the Christian Guardian exceptionally small, since that same year, the latter office was already considering moving to a new location. It is also possible that the buildings of the Christian Guardian printing office were owned by the Wesleyan Methodist Church and that the low rent was the result of a special arrangement between the church and one of its agencies. The lots for the proposed new location of the printing shop were

20 Information on paper costs for the Guardian office was obtained from the Reports of the Book and Printing Committee, 1833, Appendix to Annual Conference Minutes 1824-1854, and from the Christian Guardian I May I830 and $30 \mathrm{Jan} .1833$.

21 Canadian Freeman 22 Apr. 1830.

22 Colonial Advocate 3I Jan. I833 and Upper Canada Herald Ledger.

23 House of Assembly, "Detailed Accounts of the Government of Upper Canada for the year 1839," Appendix to the Journal of the House of Assembly of Upper Canada, $5^{\text {th }}$ Session of the $13^{\text {th }}$ Parliament, 1839-1840, Vol. I. 
owned by the church; however, since there is no record of the rent paid after the move, speculation that the rent was subsidized cannot be verified. ${ }^{24}$ As for insurance costs, Thomson was paying $£_{5}$ every two years in the early I830s in Kingston. Although at mid-century the directors of the Christian Guardian were intending to insure the type and presses for $£_{500}$ and the building for $£_{100}$, the accounts do not show the premiums for such insurance. ${ }^{25}$ The records of the Christian Guardian office also reveal ink expenses; in 1831 this office expended a little more than $\mathfrak{£}_{7}$ for this commodity. Since the prices for both English and American ink were advertised as $2 s$ per pound for newspaper ink, $3 s$ per pound for English book ink and 3s 9d per pound for American book ink, the Christian Guardian's costs represented a purchase of approximately seventy pounds of ink. ${ }^{26}$ Finally a printing office had to budget for contingency expenses which, for the Christian Guardian office, equalled the considerable sum of $£_{15}$ to $£_{22}$ annually. ${ }^{27}$ A rough calculation of the total of these expenses $-\mathfrak{£}_{4} \mathrm{O}$ for rent, $\mathfrak{£}_{5}$ for insurance, $£_{7}$ for ink and $£_{20}$ for contingencies - amounts to $\mathfrak{£}_{72}(\$ 290)$ a year for a typical Toronto shop.

The cost of labour was a printing shop's largest expense. Labour costs varied during different periods of the year and depended on the number of presses in the shop, the number of printing contracts obtained by the office, the printing expertise of the proprietor and the number of family members active in the business. In 1832 the York Typographical Society stipulated that a journeyman be paid $\$ 7$ or $\mathfrak{E I}_{\mathrm{I}}$ I5s per week. ${ }^{28}$ The staff at the Christian Guardian office in I830 included an editor, a foreman, a journeyman, and two apprentices. The editor was paid a salary of $£_{5} \mathrm{O}$ and allowed $\mathfrak{£}_{4} \mathrm{O}$ for family expenses; the foreman's wages were $\mathfrak{E}_{75}$ annually, the

24 Reports of the Book and Printing Committee, 1830, I831 and 1832, Appendix to Annual Conference Minutes I824-1854; Upper Canada Herald Ledger.

25 Book Committee Journal, 5 September 1850, United Church of Canada Board of Publication Collection I808-1871, UCC Board of Publication Series I, 83.06IC Box I, United Church of Canada/Victoria University Archives.

26 Report of the Book and Printing Committee 1832, Appendix to Annual Conference Minutes, I824-I845; The Toronto Herald 13 Jan. I845.

27 Reports of the Book and Printing Committee 1829-1831, Appendix to Annual Conference Minutes, 1824-1854.

28 Scrapbook clippings from the Toiler of extracts from the minute books of the Toronto Typographical Union, The Robert S. Kenney Collection, MS Coll 179, Box 47, Thomas Fisher Rare Book Library, University of Toronto. 
journeyman's salary was £Io8 and the apprentices each received about $£_{15}$ for thirty-six weeks' work. ${ }^{29}$ The following year the office started using smaller type to accommodate more information in the newspaper and the foreman's salary was increased to $£ 87$, while that of the journeyman was raised to $£_{144}$ and the apprentices were each paid about $£ 28$. At this time, Mackenzie's apprentices were paid on a graduated scale: $£_{2} 6$ in the first and second years, $£_{30} \mathrm{in}$ the third and fourth years, $\mathfrak{E}_{35}$ in the fifth, and $\mathfrak{E}_{45}$ annually in the sixth year. ${ }^{30}$ The Christian Guardian office also hired two assistants in I83I for a total salary of $\mathfrak{£}_{7}$ to $£_{\text {IO }}$ and a clerk for an annual wage of $£_{75}{ }^{3 \mathrm{I}}$ Therefore, the labour costs to this office for I83I including the $£_{90}$ allotted to the editor added up to about $£_{470}$. Before I833 the Christian Guardian shop worked on other printing contracts, as did most newspapers shops of the period, but it was not busy with large amounts of government printing such as the Journal of the House of Assembly or a volume of Statutes, or even reports of House committees. $^{32}$ Therefore, these labour expenses were probably representative of a typical Toronto printing shop.

In addition to the Christian Guardian, other newspaper offices of the period also hired several employees. In I830 Francis Collins, himself an experienced printer, explained that two "competent manuscript compositors" helped set the type for the parliamentary reports in the Canadian Freeman. Thomas Dalton of the Toronto Patriot needed similar help in 1835; he claimed he spent an extra $£$ Ioo in wages that year for additional employees to print the "Provincial Parliament" column. ${ }^{33}$ Most Toronto printers likely worked in one of the city's newspaper offices. In I832, twenty-four printers in Toronto joined the York Typographical Society. At that time the presses in Toronto, with the exception of very few independent printers, were in the eight newspaper shops. When

29 It is interesting to note that the editor and foreman were paid less than the journeyman printer. I can only guess that the editor and foreman were paid a yearly salary and the printer received an hourly wage; thus he must have worked an exceptional number of hours to arrive at this wage.

30 Indenture articles of apprenticeship, 4 Aug. 1836, Io Aug. 1836, and I8 Mar. 1837, William Lyon Mackenzie Correspondence, Mackenzie-Lindsey Papers.

3I For this annual salary the assistants were probably hired for a short period when the shop was particularly busy. Reports of the Book and Printing Committee, 1829-1831, Appendix to Annual Conference Minutes 1824-1854.

32 See Patricia Fleming, Upper Canadian Imprints 180I-184I: A Bibliography (Toronto: U. of Toronto P., 1988).

33 Canadian Freeman 22 Apr. 1830 and Toronto Patriot 24 Mar. I835. 
twenty-eight printers joined the Typographical Society in 1835 , the twelve newspaper offices again constituted the majority of presses. ${ }^{34}$

Costs to distribute the newspaper added to a shop's expenses. Mackenzie and George Gurnett both used couriers to some extent: Mackenzie paid the mail courier two dollars a week to deliver newspapers on his route, and Gurnett used couriers for local delivery. ${ }^{35}$ Because of the poor performance of such couriers, proprietors used the post office as the principal means of distributing their newspapers outside the local area. The cost of postage for newspapers was $4 \mathrm{~s}$ a year per copy for weekly papers and $s s$ a year per copy on a biweekly paper. ${ }^{36}$ Although this expense was passed on to customers, the cost of postage still bore "heavily upon the expenditures, for though it [was] understood the postage [was] to be paid by the subscribers and [was] returned by those who do pay, still the whole amount must be accounted for and paid by this office." ${ }^{37}$ When subscribers did not pay their newspaper accounts, newspaper offices found themselves responsible for the unpaid postage costs.

Sources give somewhat varying accounts of the postage paid by newspaper proprietors. In I83I the Christian Guardian office recorded postage expenses of $£_{22} \mathrm{O}$, and claimed that its contemporaries spent much less. ${ }^{38}$ Government records, which list the gross amount paid by newspaper proprietors for the years 1832 to I834 inclusive and again in 1840 verify the Christian Guardian's claims. According to these government records, the average postal costs for a Toronto newspaper shop in 1833 were approximately $\mathfrak{E}_{45}$, and by the $1840 \mathrm{O}$ Toronto newspaper shops either paid close to £roo in postage costs or less than $£ 20.39$

34 See extracts of the minute books of the Toronto Typographical Union in the Robert S. Kenney Collection and list of imprints in Fleming's Upper Canadian Imprints I80I-184I.

35 Colonial Advocate 14 Apr. 1825 and Courier of Upper Canada 29 Feb. 1832.

36 Legislative Assembly, "Report of the Commissioners Appointed to Enquire into the Affairs of the Post Office in British North America," Appendices to the Fifth Volume of the Journals of the Legislative Assembly of the Province of Canada, I846, Appendix F.

37 Report of the Book and Printing Committee 1831, Appendix to Annual Conference Minutes, I824-1854.

38 Report of the Book and Printing Committee 1831, Appendix to Annual Conference Minutes 1824-1854, and the Christian Guardian 23 Oct. I833.

39 House of Assembly, "Public Accounts," Appendix to the Journal of the House of Assembly of $U_{p p e r}$ Canada, $2^{\text {nd }}$ Session of the $12^{\text {th }}$ Parliament, 1836, Vol.r; Legislative Assembly "Report of the Commissioners Appointed to Enquire into the Affairs of the Post Office in British North America." 


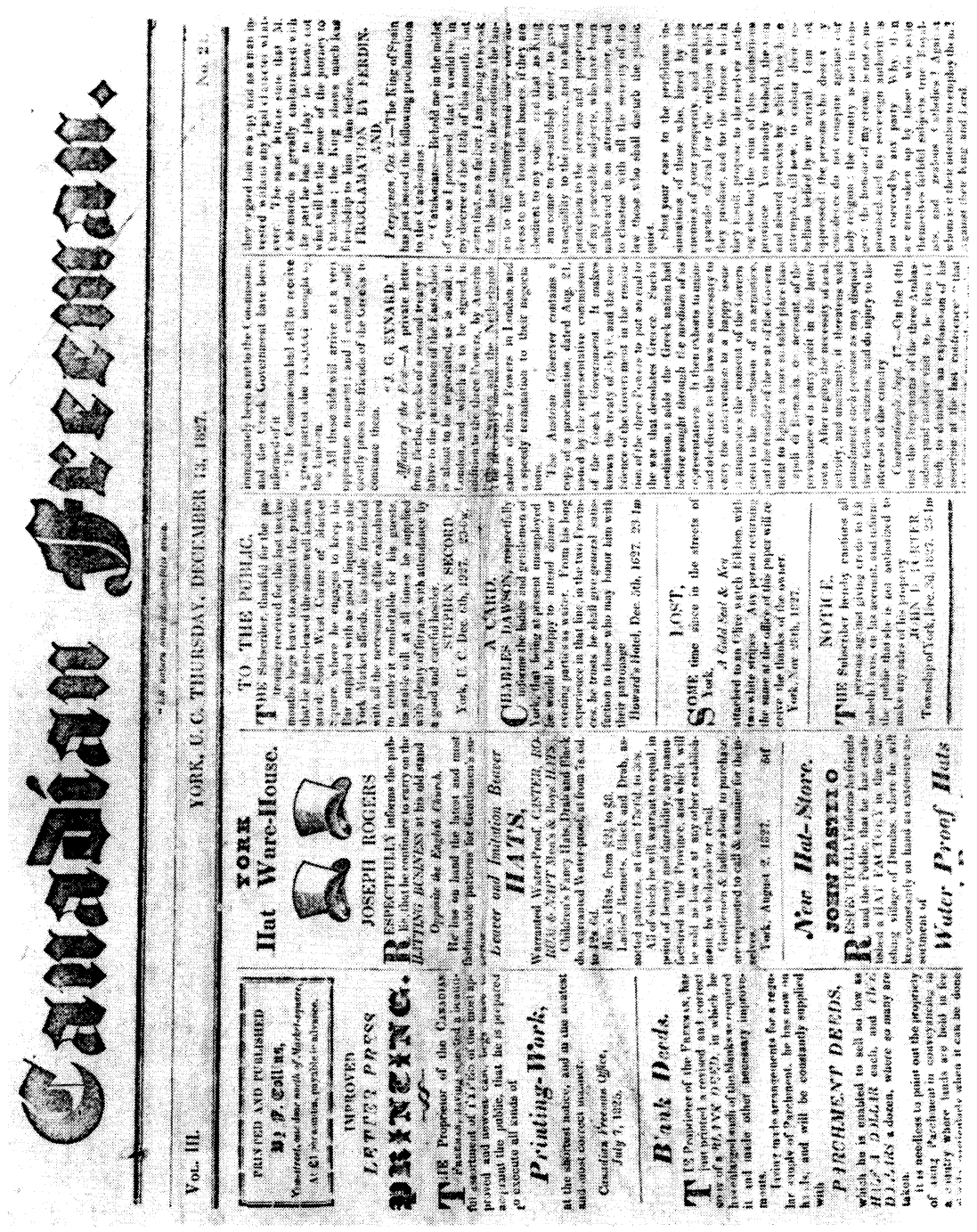

Figure 3. Canadian Freeman, 13 December 1827 . Reproduced from a copy held at the Metropolitan Toronto Reference Library, Baldwin Room. 
The above figures, however, are not realistic indicators of circulation. Besides the post office, proprietors used various other methods for newspaper distribution. In addition, each quarter, proprietors paid a postal fee based on a statement of the number of newspaper copies they intended to mail. This statement was not questioned and frequently fell short of the actual number posted. ${ }^{4}$ Postmasters had problems with this arrangement, for they strongly suspected attempts at fraud by some proprietors. James Howard, postmaster at Toronto, suggested regulations to eliminate cheating to Thomas Stayner, deputy postmaster general at Quebec. However, Stayner believed Howard's suggestions would "draw a hornet's nest about [his] ears," and not only would be difficult to enforce, but also would punish honest proprietors. Although he too believed that some proprietors were "notoriously unprincipled and [would] not scruple to take every advantage, yet [they could] not in [their] regulations make any difference between them and those [they] believe[d] disposed to act honestly; every concession you make to the former class is sure to lead to abuse in some shape or another." ${ }^{41}$

Toronto proprietors who were negligent in remitting their postal fees suffered the consequences of Stayner's wrath. In the early I830s, Stayner instructed Howard that if James King of the Canadian Correspondent "[did] not pay up the whole of his debt, [he was] to rate this paper with letter postage." During the same period Thomas Dalton of the Toronto Patriot and George Gurnett of the Courier of Upper Canada were denied the usual privilege of paying at the end of each quarter, and had to pay singly for each newspaper at the time of mailing until they had discharged their debts. When Mackenzie was in arrears for his payments, Stayner declared that Mackenzie's "conduct in this affair [was] most infamous and that if he [Mackenzie] had any sense of shame in him, [Stayner] would [have] exposed him to the public, but a man who could act as he [had] done, must be lost to every feeling of self respect." 42

Proprietors' problems with postal payments reflected their difficulties in meeting the shop's expenses. Mackenzie, for example, complained frequently of lack of funds. In 1824 he wrote that he

40 Legislative Assembly, "Report of the Commissioners Appointed to Enquire into the Affairs of the Post Office in British North America."

$4 \mathrm{I}$ Thomas Stayner to James Howard, I3 June 1835, Postal Services, Appendix I, Howard Maclean Papers, MU 1384, Archives of Ontario.

42 Stayner to Howard, 23 Jan. 1833, 22 Nov. 1834 and 5 Dec. 1834, Postal Services, Appendix I, Howard Maclean Papers. 
"was not able to pay the necessary number of hands to get the paper out regularly." Barnabas Bidwell sympathized with him in 1827 because the "printing business [was] not more productive of profit." 43

In this discussion I have tried to determine an estimate of the annual expenses for a typical shop in the I830s. To recapitulate, I calculated these "typical" expenses to be as follows: $£_{3}$ o for additional equipment (the average amount spent by Mackenzie and Thomson), $£_{130}$ for paper, $£_{40}$ for rent (the amount allotted Stanton), $£_{5}$ for insurance, $\mathfrak{£}_{7}$ for ink, $\mathfrak{£}_{20}$ for contingencies, $\mathfrak{£}_{470}$ for labour and $£_{45}$ for postage. The typical total tallies to $£_{747}$ in expenses per year. The Christian Guardian office claimed that in 1830 its expenditures amounted to $\$ 60$ per week or $£ 9 I 1$ per year. This office spent about $£_{200}$ in postage, an amount much higher than the estimated average of other shops. If one were to replace the approximately £200 spent on postal fees with $\mathfrak{E}_{45}$ (the estimated amount for a typical shop), the total expenses would be $\mathfrak{1}_{756}$, an amount comparable to my estimated total of $£_{747}$.

By 1838 the Christian Guardian's costs had increased to E129I per year. According to this office, these expenses could be met if all subscribers paid their fees. ${ }^{44}$ The difficulty in collecting these fees proved to be the bane of every newspaper office.

\section{Revenue}

From the first years of the century, editors of the Upper Canada Gazette urged their agents to try harder to secure fees from subscribers. ${ }^{45}$ In subsequent years, newspaper proprietors continued to lament the problems caused by non-paying customers. The frustrations of Francis Collins, proprietor of the Canadian Freeman, are typical: "We beg leave to inform our readers that this number closes the labour of five years, and again we request those who are in arrears to make us a remittance, as together with our other expenses, we have got our hands dipped in mortar and our workmen are pressing for the needful." ${ }^{6}$ Collins' plea went unheeded. Angry that

43 Mackenzie to Charles Jones in Brockville I Dec. I824, and Barnabas Bidwell to Mackenzie I2 Nov. I827, William Lyon Mackenzie Correspondence.

44 Reports of the Book and Printing Committees, I830 and I838, Appendix to Annual Conference Minutes 1824-I854; Christian Guardian 25 Sept. I830.

45 Upper Canada Gazette I6 July I8Io.

46 Canadian Freeman 24 June 1830. 
only "one of every twenty that take [the] paper ever think of paying a shilling," Collins resorted to more severe tactics to obtain his fees. $\mathrm{He}$

gave notice that at the close of the quarter, he would cut away from all lip friends, and that eight weeks from this, the Freeman [would] be forwarded to no man out of York who [would] not pay in advance, according to the original terms... Subscribers [would] then know by a blue cover sent round in their papers for two or three weeks previous to the expiration of their time, that another remittance alone can secure to them the perusal of the paper... It [was] folly for an editor to call his paper free and independent while he [was] the slave of a set of mock patrons who under pretence of supporting a free Press [were] doing everything in their power to crush it. ${ }^{47}$

Even the publication of a "blue list" and the receipt of the newspaper in the telling "blue covers" did not remedy this problem; the following year, the "arrears owed by the first forty-two subscribers that [Collins] selected amounted to $\$ 480 . " 48$

Mackenzie experienced similar difficulties. When $\$ 1400$ was owed to him on Colonial Advocate accounts in I825, he sent Mr. James Don on a "collecting tour." After eleven weeks of travel, Don was able to collect only $\mathfrak{E}_{42}$ I3s Iod, and charged Mackenzie $£_{15}$ for his efforts. Unable to generate adequate income from his newspaper, Mackenzie decided to continue the paper "in the manner of a sketch book, that is at uncertain periods," so that he could devote his time to more lucrative printing pursuits. ${ }^{49}$ Exclaiming that he "[did] not doubt for a moment that other printers [were] as poorly paid as [he] by their subscribers," Mackenzie merely confirmed an all-toocommon situation.

Although most proprietors adopted the practice of publishing a "blue list" and of sending newspapers in blue covers to people in arrears, they still continued to be plagued by non-paying subscribers. ${ }^{50}$ The severity of this problem is illustrated by the Christian Guardian

47 Canadian Freeman I5 July i830.

48 Canadian Freeman 23 June 1831.

49 The information on Mackenzie's problems with non-paying customers is from the Charles Lindsey Draft Articles, Box I20, Envelope 5, Mackenzie-Lindsey Papers, and from the Colonial Advocate I8 Apr. and 12 May I825.

50 The practice of sending the newspaper in blue covers to subscribers in arrears is mentioned in the Correspondent and Advocate 6 Feb. 1835; the Christian Guardian I6 Sept. I835; and Examiner 8 July I840. 


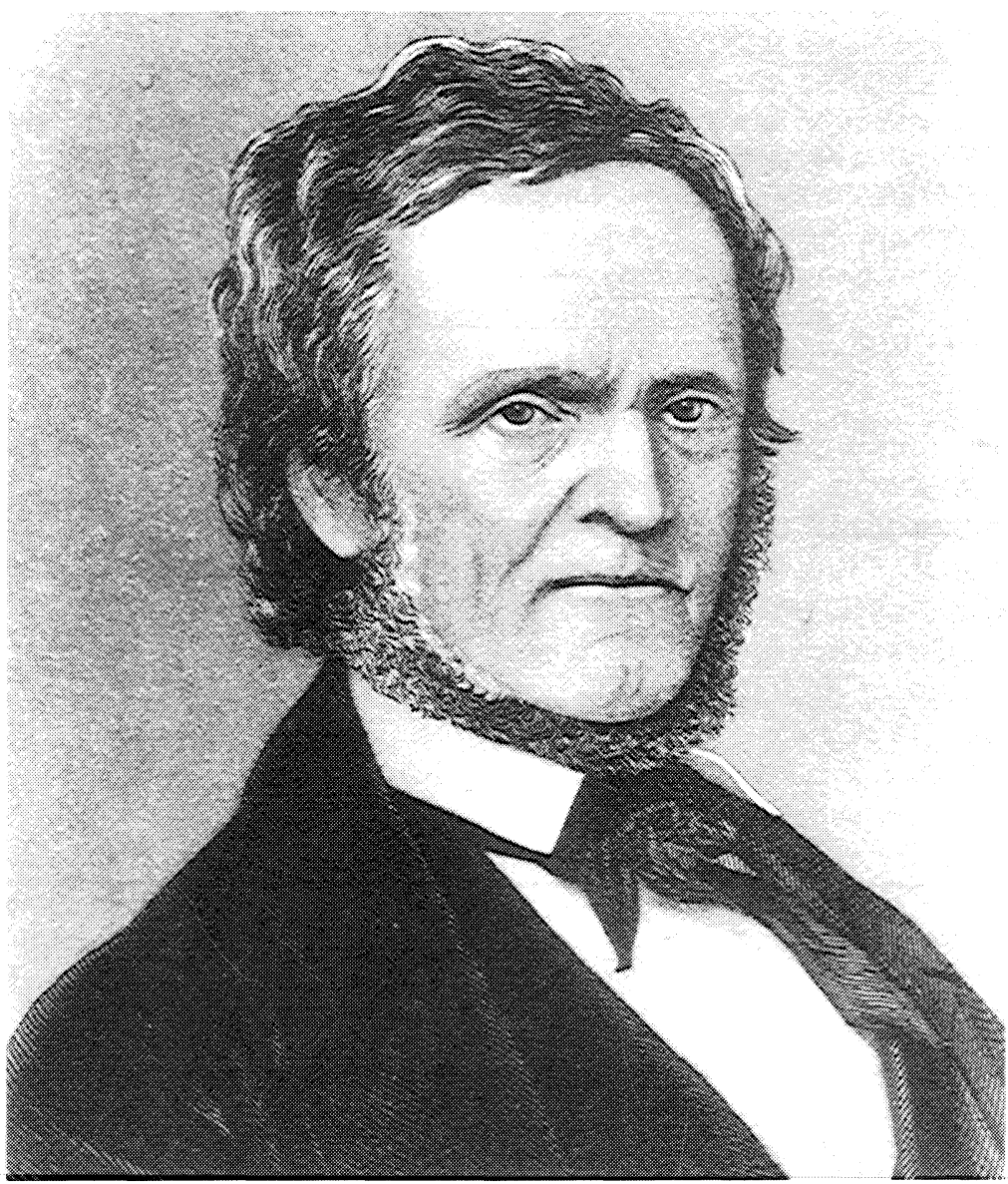

Figure 4. William Lyon Mackenzie, proprietor and editor of the Colonial Advocate. Reproduced from a negative held at the Archives of Ontario ( $\mathrm{S}_{2123}$ ). 
office, which recorded the number of unpaid subscriptions. In 1830 only 700 of the newspaper's 1250 subscribers had paid; from a total of $£ 892$ due from subscription fees the office had received $£_{4} 65$. The following year the amount due from subscribers had risen to approximately $£_{1373}$, of which only $£_{7} 80$ had been paid. When this shop had been in operation for three years in 1832 , "more than 60 subscribers [were] yet receiving the Guardian who [had] not paid for the first volume, 273 who [were] indebted for the second volume, and 715 for the third"; a total of £II46 was outstanding from unpaid subscriptions. The situation did not improve in 1834, when more than one half of the Iroo subscribers had not paid their accounts. At this point the directors of the conference decided that the names of those who were eighteen months in arrears were to be removed from the subscription list; the amount due from these delinquent accounts totalled $£_{928}$, of which only $£_{42}$ had been collected. Although subscribers paid $£_{1542}$ in fees in the next two years, $£_{1346}$ was still unpaid. Frustrated, the printing committee appointed a special agency to collect subscription debts, and stipulated that payment for this service would be a percentage of the amount collected. However, the status quo still did not change. In 1838 only one half of the newspaper's I279 subscribers paid their accounts in advance. These provided a revenue of $£ 870$, but the total due from non-paying subscribers was $£$ 1925. After a few years, subscription revenues remained constant: $£ 935$ in 1841 and $£ 835$ in 1842 . But the number who did not remit their fees also did not change: in 1843,250 subscribers were three and four years in arrears. The printing committee entertained the idea of discontinuing credit for a newspaper subscription and of allowing only cash transactions. Because of the debtor economy that characterized Upper Canada, this solution would have eliminated many subscribers, including those who eventually paid their accounts. ${ }^{51}$ The problem of collecting fees continued unsolved. ${ }^{52}$

Proprietors' financial difficulties were compounded by subscribers who failed to give notice when they wanted to cancel their subscriptions; these clients simply did not pick up the newspaper at the post office or other delivery station. The publisher continued to

5I For a discussion on the credit system prevalent in Upper Canada at this time, see McCalla, especially chapter 8.

52 The preceding information on subscriptions and revenue of the Christian Guardian is from the Reports of the Book and Printing Committee, I829-I85I, Appendix to Annual Conference Minutes, I824-1854. 
mail the newspapers until the post office informed him that they were not being retrieved. Newspaper owners never collected on these accounts. As early as 1820 the editors of the Upper Canada Gazette felt this predicament was serious enough to warrant a notice with the colophon of the newspaper:

Country subscribers, who send to the post office for their papers, who discontinue their subscriptions are requested to send notice to that effect and pay up all arrears, otherwise they will still be considered as subscribers and charged accordingly. The editor is obliged to insist upon this condition, several subscribers neglecting frequently for many months to send for their papers, which accumulate to an inconvenient degree, and become if not paid for, a serious loss. ${ }^{33}$

By mid-century customers who cancelled subscriptions without informing the newspaper office provoked the editors of the Toronto Mirror and the Examiner to publicly complain of the loss resulting from this practice. In an attempt to threaten offending persons of possible legal repercussions, the Examiner published the provisions of a law in Nova Scotia which held subscribers responsible for payment until they had given notice to the editor of their intention to cancel their subscription and had paid all arrears. ${ }^{54} \mathrm{I}$ have not found any evidence to confirm whether a similar law was adopted in Upper Canada.

Because of difficulties in collecting subscription fees in cash, proprietors agreed to accept payment in goods. In 1809 the $U p p e r$ Canada Gazette announced that "country subscribers who [were] in arrears for the Gazette and for advertisements ... [were] requested to leave the amount in any Grain advertised to be purchased by Mr. St. George." "S Presumably the printing office had made arrangements for payment with Mr. St. George. Mackenzie advertised that "wood and country produce [would be] generally received in payment for the Colonial Advocate" or that "paper rags" would be gladly accepted in lieu of payment at $3 \mathrm{~d}$ per pound. ${ }^{56}$ "Cords of wood," "Io bags bran," "one barrel flour," "40 dozen eggs" and "butter" were some of the goods accepted by Hugh Thomson as payment for his newspaper. ${ }^{57}$

53 Upper Canada Gazette I3 Jan. 1820.

54 Examiner 15 Jan. 1845 and Toronto Mirror 7 Mar. 1845.

55 Upper Canada Gazette 22 Feb. I809.

56 Colonial Advocate 3 Feb. 1825 and I5 Dec. 1825.

57 Upper Canada Herald Ledger F 4269. 
In the early nineteenth century, as today, advertising constituted the main source of revenue for a newspaper shop. Roger Parkinson, former publisher of today's Toronto Globe and Mail, provides statistics on the importance of advertising to the financial success of a newspaper: "Circulation sales account for about twenty per cent of our revenue and newspaper advertising sales sixty-six per cent, other business units represent fourteen per cent." ${ }^{18}$ The necessity for advertising income was realized also by nineteenth-century proprietors. The editor of the Montreal Herald claimed in 1832 that "the returns on a newspaper in Canada would not be sufficient to pay the expenses were it not for advertisements." 59 The editor/ proprietor of the British Colonist repeated these facts to his readers when he attempted to explain the large number of advertisements in his newspaper: "the bare subscriptions to a paper like this would not of themselves be sufficient to sustain it even if punctually paid in advance. The advertisements are depended upon to make up the deficiency." ${ }^{60}$ Although the Christian Guardian was among the newspapers with the fewest number of advertisements, it still received complaints from readers about the extent of the advertising section. The editor's response explained how vital these few advertisements were to the economic success of the newspaper:

If our yearly receipts were sufficient, no doubt the book committee would exclude advertisements altogether from the paper, as is done in some of the Methodist papers in the United States. But we can assure our correspondent and our friends in general, that the Christian Guardian is no 'profitable speculation' as is intimated. With so few advertisements as we generally have, a large circulation is necessary, or it is impossible that a paper can pay expenses. Though our subscribers are pretty numerous they are not sufficiently so to make the paper profitable. ${ }^{61}$

Although the amount of newspaper space occupied by advertisements doubled from 1800 to 1845 , the rates charged for print advertising did not change noticeably. Competition for

58 Roger Parkinson, "Notes from the Publisher," Globe and Mail 25 May 1998: A2.

59 Montreal Herald as quoted in the Courier of Upper Canada 13 Oct. 1832.

60 British Colonist 5 Aug. I845.

6I Christian Guardian I2 Feb. 1845. 
advertisers caused these rates to be uniform among the city's newspapers. The standard rates were as follows:

Six lines and under

Six to ten lines

Above ten lines 2s $6 \mathrm{~d}$ for the first insertion, and $7^{1 / 2} \mathrm{~d}$ for each subsequent insertion 3s $4 \mathrm{~d}$ for the first insertion, and rod for each subsequent insertion $4 \mathrm{~d}$ per line for the first insertion, and Id per line for subsequent insertions

When woodcuts or other ornaments were used, the advertiser was charged in proportion to the entire space occupied. When the business directory column became commonplace in the 1840 s, a four-line card cost $£$ I per annum and 5s annually for each additional line. The Globe's rates for publishing such a business card were slightly higher: $£_{1}$ I 5 s per annum and $\mathfrak{E}_{\mathrm{I}}$ for a six month insertion. The Globe and its sister paper, the Banner, also charged higher prices for standard advertisements; however, they claimed to have the lowest prices in the province because clients of one paper could advertise in the other at half price. The Banner and the Globe also extended a 10\% reduction for an advertisement occupying roo lines, a $15 \%$ reduction for one of 150 lines in length and a $20 \%$ reduction for a whole column or 200 lines. Similarly, they offered a $5 \%$ reduction for an advertisement running three months, a IO\% discount for a sixmonth advertisement and a $20 \%$ discount on one continuing for an entire year. ${ }^{62}$ Discounts for long advertisements and for those inserted for a substantial period of time were probably common to all newspapers.

The price of a standard advertisement consisting of six to ten lines, 25 6d, was not inexpensive. During the second and third decades of the century this advertisement cost the same as twelve pounds of beef, or four pounds of butter, or was the equivalent of one-half day's work by a tradesman or one day's work by a labourer. As the prices of commodities decreased in the middle of the century, the same advertisement cost the equivalent of five pounds of butter.

Some of the advertisers most coveted by newspaper proprietors were governments because they represented a secure and steady income. The provincial government advertised chiefly in the official Upper Canada Gazette but also placed advertisements in other

Q Banner 7 Feb. 1845 . 
newspapers. Mackenzie did not disguise his bitterness at not obtaining an advertising account when he published the following government expenses:

To Robert Stanton $£_{17} 17$ o for printing in his Gazette, which few see, the list of the sales of wild land for assessment.

To John Carey $£_{17} 17$ o for reprinting and publishing this same land sale in the York Observer, a paper which Mr. Billings well knew had scarcely the name of circulation in this country. ${ }^{6}$

With the incorporation of the city of Toronto in 1834 the local government also paid city newspaper proprietors for advertising. In I835 the Courier of Upper Canada received approximately $£_{45}$ from government advertising and the Christian Guardian £20, while the Toronto Patriot gained $£_{15}$ from advertisements from the municipal government alone. ${ }^{64}$ These advertising contracts were patronage plums, and therefore, loss of favour with government authorities resulted in a considerable loss of revenue. The Toronto Patriot suffered a financial upset in 1840 when it lost the commissariat advertising contract to the Christian Guardian. For this reason, papers which didn't secure government advertising expressed strong disappointment. The Toronto Mirror claimed that it was the only paper that did not receive the patronage of the city corporation or the "bread and butter from the highest municipal body in the province." ${ }^{65}$

The records of the Christian Guardian office provide only inconclusive evidence of the revenue generated by advertisements. When first established in 1830 this shop collected approximately $£ 6$ and was owed another $\mathfrak{£}_{29}$ from advertisements. As the newspaper became established this revenue increased. In I83I advertisers paid the office $\mathfrak{£}_{21}$ and owed it another $\mathfrak{6 6}_{2}$. However, records for subsequent years combine advertising revenue with that from job printing. In 1838 these two sources generated $£_{715}$ for the shop. ${ }^{66}$

63 Colonial Advocate 26 Aug. 1830.

$64 £_{45}$ represents the yearly wage of a labourer during this period or a year's supply of new type, and $£ 20$ paid half a year's rent or a year's worth of contingency costs.

65 Examiner II Mar. 1840 and the Toronto Mirror 9 Oct. and 24 Dec. 1840.

66 Reports of the Book and Printing Committees, I830, I831, and I838, Appendix to Annual Conference Minutes, I824-I854. The only other record of the period which itemizes advertising revenue is the ledger of Hugh Thomson's $U_{p p e r}$ Canada Herald in Kingston. In addition, since the Herald ledger is organized by client and since the years for each entry are not always clear, calculating yearly advertising income would be very time consuming and difficult. 
How much of this income can be attributed to advertising is indeterminable. Moreover, these figures are not representative of most newspapers shops. In 1830 the Christian Guardian allocated only I0\% of its newspaper space to advertising, while other city newspapers allotted an average of $44 \%$ to this section. Despite obtaining the commissariat advertising contract in 1840, the Christian Guardian still published half as many advertisements as the other newspapers.

Calculations using published rates and the number of advertisements in newspapers would not be very accurate. As noted, proprietors gave discounts for long-term insertions and for larger advertisements. In addition, although insertion codes indicated duration of the advertisement, they were not always consistently used, and the specified duration was frequently ignored to facilitate printing of the newspaper. It is unclear if the advertiser was responsible for payment of these additional insertions. Members of the print trade and druggists, who had a special relationship with newspaper proprietors/printers, paid a reduced advertising rate, or paid in kind or by an exchange of services. Advertising fees, like subscription accounts, were sometimes settled with produce or other goods, such as wood or rags, and a number of advertisements were inserted pro bono. Finally, the proprietor used this section of the newspaper to liberally advertise printed matter - books, pamphlets, forms - that he sold and services that he provided. All of these conditions do not detract from the value that proprietors gained by publishing these advertisements, but render it difficult to attribute a cash figure to the advertising section of the newspaper.

The government remunerated newspaper proprietors who recorded and printed the debates and proceedings of the House of Assembly. Until I83I, the proprietors of the Observer and the Canadian Freeman, Carey and Collins respectively, transcribed and published these parliamentary proceedings, which were then copied by other newspapers. ${ }^{67}$ Although Collins and Carey each had been paid £roo for printing the debates, Collins complained that most of this money had gone towards the wages of two competent manuscript compositors. He noted that the other city newspapers could provide readers with the same information at no cost, because they could use an ignorant office boy to copy the published reports. ${ }^{68}$ In subsequent

67 Toronto Patriot $\mathrm{I} 4$ Apr. 1835 .

68 Canadian Freeman 22 Apr. 1830. 
years, several newspapers were paid to publish the proceedings of parliament. The amounts given to each newspaper varied, and perhaps depended upon the number of newspapers supplied to members of the House of Assembly. By the middle of the I83os a dispute arose between John O'Grady of the Correspondent and Advocate and Thomas Dalton of the Toronto Patriot about the actual amounts they received from the Assembly. O'Grady claimed that the Assembly did not pay his newspaper and its predecessor, the Colonial Advocate, even though they carried the reports of the House, because their political platforms opposed the policies of the administration. ${ }^{69} \mathrm{On}$ the other hand, Thomas Dalton maintained that the Colonial Advocate was paid $£_{225}$ and the Correspondent and Advocate was given $£_{125}$. He criticized the House of Assembly for remunerating these newspapers when they had not hired a reporter to transcribe the parliamentary debates and consequently did not provide adequate and accurate coverage of these proceedings. Shortly after this dispute the Assembly authorized payment of $£_{75}$ per session to four newspapers for printing the debates of the House: the Courier of Upper Canada, the Christian Guardian, the Correspondent and Advocate and the Toronto Patriot. It also agreed to pay three reporters for these newspapers - Mr. Fowler, Mr. Junkin, and Mr. Reynolds another $£_{75}$ each for the session. In making this decision the House stipulated that the other newspapers could copy these published accounts indiscriminately. ${ }^{70}$

Because newspaper shops could not survive from newspaper revenue alone, most proprietors sought other sources of income. Since they had an operating printing shop most tried to do as much contract work and job printing as possible. Some of the most lucrative printing contracts were those from the provincial government, whose printing requirements included the Journal of the House of Assembly, the Appendices to the Journal of the House of Assembly, the Journal of the Legislative Council, volumes of the Statutes passed in each session, copies of individual acts and bills, and numerous reports of the committees of the House of Assembly and of the Legislative Council, as well as sundry proclamations, notices, pamphlets, and circulars.

The contract for the Journal of the Legislative Council as well as that for printing the volume of Statutes for each parliamentary session

69 Correspondent and Advocate i8 June I835.

70 Toronto Patriot 27 June 1835. 


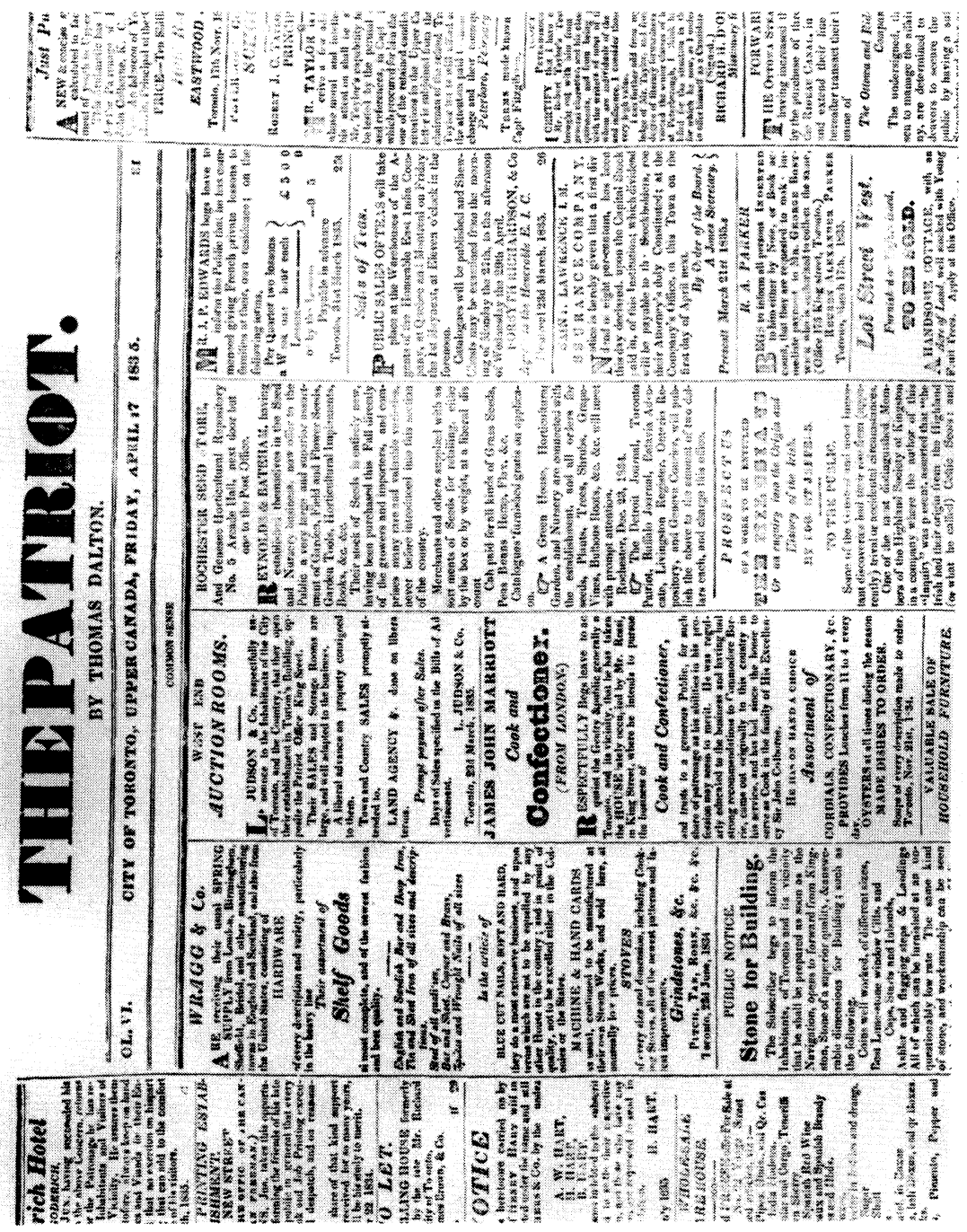

Figure 5. The Patriot, 17 April 1835 . Reproduced from a copy held at the Metropolitan Toronto Reference Library, Baldwin Room. 
was awarded usually to the King's Printer. ${ }^{71}$ In 1825 Mackenzie stated that Fothergill, as King's Printer, had earned not less than $£ 3000$ the previous year, of which $£ 882$ was for printing the Statutes. Mackenzie claimed that he could have printed the laws for less than £Ioo. He suggested that government printing should be done by contract and that payment should be in the form of a fixed sum per IOoo ems and not by a wage. ${ }^{72}$ The Legislative Council also felt that Fothergill's price for printing the Statutes had been extravagant, noting that he had used larger type than customary in addition to excessive leading. Following Mackenzie's suggestion, they called for proposals and gave the contract to Kingston printer James McFarlane, the lowest of five bidders. ${ }^{73}$ The government must not have been pleased with his work, for in 1826 the Statutes were again printed by King's Printer, Robert Stanton, who maintained this contract until he lost his position in I84I when the seat of government was transferred from Toronto to Kingston following the union of Upper and Lower Canada into the Province of Canada. The fees for printing the Statutes were lucrative. In I834 Robert Stanton was paid $£ 1320$ I8s $6 \mathrm{~d}$ for printing and stitching 3500 copies of the volume of Statutes, each copy consisting of 304 pages, and in 1839 he was paid £595 4s od again for printing and stitching 3500 copies, each copy consisting of 136 pages. ${ }^{74}$ When he lost the contract for printing the Statutes in I84I, Robert Stanton claimed that he had lost three quarters of his income. ${ }^{75}$

The contract for printing the Journal of the House of Assembly was assigned after reviewing proposals from printers. A number of newspaper proprietors, including John Carey, Francis Collins, William Lyon Mackenzie, John O'Grady, Thomas Dalton, Hugh

71 During the sessions 1813 to 1815 the Statutes were printed in Kingston by Stephen Miles, and in 1825 this contract was awarded to another Kingston printer, James McFarlane. See Fleming, Upper Canadian Imprints I80I-I84I, \# 242.

72 Colonial Advocate 17 Feb. and 28 Feb. 1825. An em is a standard for typographic measurement used for computing the area of a printed page.

73 Fleming, Upper Canadian Imprints I80I-184I, \# 242.

74 House of Assembly, "Detailed Accounts," Appendix to the Journal of the House of Assembly of Upper Canada, I $^{\text {st }}$ Session of the $12^{\text {th }}$ Parliament, I835, Vol. I; House of Assembly, "Detailed Accounts," Appendix to the Journal of the House of Assembly of $U_{p p e r}$ Canada, $5^{\text {th }}$ Session of the $13^{\text {th }}$ Parliament, 1839-1840, Vol. I.

75 Robert Stanton Narrative Memoranda, 6 Sept. 1841, Manuscript Collection 5116, Thomas Fisher Rare Book Library. 
Scobie, and the office of the Christian Guardian, won this contract during the first half of the century. At times, the contract for printing 800 copies of the Journal - the number required in the 1830 - was shared by several printers. ${ }^{76}$ In 1825 Carey requested payment of $£_{343} 6 \mathrm{~s}$ 9d for printing an estimated 200 copies of the Journal and in I832 Stanton was paid $£ 259$ I6s $3 \mathrm{~d}$ for printing 230 copies, ${ }^{77}$ while Mackenzie claimed that in 1829 he was paid £IOS I4s 6d, Collins received $£$ IIO I3s od and Carey $£ 75$ I2s $6 \mathrm{~d}$ for fulfilling this contract. ${ }^{78}$

In addition to these large printing jobs, the government awarded contracts for printing committee reports, proclamations, notices, and the numerous forms used by government agencies and departments. For example, the Christian Guardian shop printed the blank forms used by the post office department in I830. Stayner, the deputy postmaster general, asked that the account from this office include both the price of printing and that of the paper; therefore, in this case, the printing office could deduct the expenses for paper. ${ }^{79}$ Mackenzie reported that the House of Assembly paid the following amounts for sundry printing to newspaper proprietors in I829: he received $£_{33} 6 \mathrm{~s}$ Id, Collins was paid $£_{24}$ IOs 6d, Carey $\mathfrak{£}_{21} 5 \mathrm{~s} 7 \mathrm{~d}$, and the Christian Guardian office received $£_{5} 6 \mathrm{~s} 3 \mathrm{~d} .^{80}$ If these payments were supplemented by the amounts disbursed for paper, they added considerably to the printers' income. However, government contracts were elusive and could be decided by political patronage. In I830, Collins sounded quite bitter when he stated that government printing contracts given to the Christian Guardian office were obviously controlled by "Pope Ryerson and the saddlebag faction." 81

With the incorporation of the city of Toronto, newspaper proprietors/printers competed for contracts from the local government. In the latter half of 1835 , three Toronto printers received a total of $£ 65$ as payment for printing jobs: George Gurnett of the Courier of Upper Canada, John O'Grady of the Correspondent and Advocate, and George Bull of the Toronto Recorder. ${ }^{82}$ In 1839 because

76 House of Assembly, "First Report of Select Committee on Printing," Appendix to the Journal of the House of Assembly of Upper Canada, $\mathrm{I}^{\text {st }}$ Session of the $\mathrm{I}^{\text {th }}$ Parliament, I836- 1837.

77 Fleming, Upper Canadian Imprints, \# 275, 351, and 668.

78 Colonial Advocate 30 Sept. 1830.

79 Thomas Stayner to James Howard, postmaster at York, I3 Mar. 1830, Postal Services, Appendix I, Howard Maclean Papers.

80 Colonial Advocate 30 Sept. 1830.

81 Canadian Freeman 22 Apr. 1830.

82 Christian Guardian 20 Jan. 1836. 
the city's printing requirements were greater, £II9 was paid for printing to Thomas Dalton of the Toronto Patriot. George Hackstaff and John Rogers of the Commercial Herald and William Coates, owner of a book and job printing shop, shared the other contracts for a total of $£ 86 .{ }^{83}$ These contracts also were assigned as patronage prizes and in 1840, upon the recommendation of Lieutenant Governor Sydenham, the Toronto Patriot lost the significant city account to the Christian Guardian. ${ }^{84}$

Newspaper shops vied for printing jobs from the general public as well as from the government. Each newspaper announced that its office printed deeds, circulars, cards, and blank forms "all executed as neatly and as quickly as possible." Many times shops acted as publishers for organizations and individuals; the following are but a few examples of many similar publications: in 1828 the Colonial Advocate office published the first report of the Central Committee; in I83I the Christian Guardian office published the second report of the York Bible Society; in 1833 the Canadian Correspondent shop published the first report of the Upper Canada Religious Tract and Book Society; in 1834 the Toronto Patriot shop published the catalogue of the Society of Artists and Amateurs; in I835 in addition to publishing sermons, the Christian Guardian office also published Iooo copies of the memoirs of Samuel Hick and sold them at a much lower price than the English edition. ${ }^{85}$ Each year a shop printed many other items in addition to the newspaper; witness the following examples. In i83i Mackenzie printed a Bible of 68 pages, an almanac of 16 pages and a public notice of two pages, in addition to his newspaper and government printing. In I840 the office of the British Colonist had acquired contracts to print the Journal of the House of Assembly consisting of $4^{16} 6$ pages, another address of parliament occupying four pages, and the following private jobs: a prayer book of 34 pages, a curling manual consisting of 42 pages, a discourse by W. T. Leach of 20 pages, an eight-page correspondence between members of a racing club, the minutes of the meeting of the Synod of the Presbyterian Church of Canada consisting of 44 pages, and a 26-page thesis on language by Thomas Stratton. That year, in addition to the newspaper, the office printed 594 pages multiplied by the number of copies required by each job.

83 Toronto Patriot 7 Aug. I840.

84 Examiner II Mar. I840.

85 Fleming, Upper Canadian Imprints I80I-I84I; and Report of the Book and Printing Committee I835, Appendix to Annual Conference Minutes I824-I854. 
The revenue generated by private printing contracts is generally unknown, although the records of the Christian Guardian office list a few figures. In 1829 this shop collected $£_{22}$ in payment for printing from the House of Assembly and another $£_{22}$ from private jobs. It was owed another $£_{37}$, but the records do not stipulate whether this debt was from government or private contracts. The following year the office collected $£_{37}$ from job work and another $£_{60}$ was still due, but whether these were private or public jobs, again, is not indicated. In subsequent reports the revenue from job printing was recorded as one sum with that from advertising. From these combined sources the shop earned approximately $£_{490}$ in $1835, £_{305}$ in $1836, £_{600}$ in 1837 , and $£_{715}$ in 1838 . Since this newspaper office allocated a small amount of space to advertising compared to other shops, the bulk of this income was probably generated by job contracts. By 1844 the records indicate that the shop collected $£_{300}$ solely from job work, but again do not stipulate whether this was public or private work. ${ }^{86}$

In addition to printing, newspaper proprietors offered other services to the book trade. Shops sold books and stationery and regularly listed these in their papers. In I8I5 Edward McBride advertised a long list of books available in the Upper Canada Gazette office. ${ }^{87}$ Mackenzie always itemized the numerous books in his shop and stated that he would get books not in stock "on short notice if available in the United States." ${ }^{18}$ In 1840 James Lesslie, soon to become proprietor of the Examiner, professed to have 10,000 to 15,000 volumes of books in his store, while the list of books sold by Hugh Scobie in 1845 occupied almost one and one-half columns in his British Colonist. At this time Scobie had a very diversified business, for he also offered book binding and lithographic printing services. ${ }^{89}$ Again, the records of the Christian Guardian office indicate what revenue was generated from books. In 1837 this office, which sold a large number of books in the depository of the book room, netted approximately $£_{355}$ from the sales of books, while in 1842 it received $£ 520$ in cash sales and another $\mathfrak{E}_{1350}$ from books sold on credit. ${ }^{90}$

86 Reports of the Book and Printing Committee, I829-1844, Appendix to Annual Conference Minutes, I824-1854.

87 Upper Canada Gazette 9 Sept. I815.

88 Colonial Advocate is Dec. 1825.

89 Examiner 8 Jan. 1840 and the British Colonist II Feb. I845.

90 Reports of the Book and Printing Committee, I837 and I842, Appendix to Annual Conference Minutes, I824-1854. 
Newspaper proprietors also earned income from a myriad of other sources. Some were agents for American and British newspapers, and offered to deliver these newspapers along with their own. ${ }^{91}$ Some represented other commercial establishments: George Brown of the Globe was an agent for the Hoe Printing Press and Manufacturing Company of New York, and the Toronto Herald office represented the American firm of Sylvester and Company, which placed large advertisements for lotteries in Toronto newspapers. ${ }^{92}$ John Carey of the Observer offered to carry "all letters and parcels left at this office" along with the newspaper to areas surrounding the city. ${ }^{93}$ Finally, a large number of printers/proprietors were active in political office. These included: Charles Fothergill when he was employed as King's Printer, the highly vocal Mackenzie, and the influential Francis Hincks in the years leading up to responsible government. Thomas Dalton and Hugh Scobie had less conspicuous political roles, while Robert Stanton quietly "served in various civil departments of the government for nearly twenty-eight years" while he held the office of King's Printer. ${ }^{94}$

From this fragmented evidence of the income generated by some newspaper proprietors, I will calculate the revenue of a typical shop by following two scenarios. For the first scenario I will calculate the revenue of the Christian Guardian office for 1835 from the records of the book and printing committee. In that year the records note $£ 749$ as income from subscription fees and another $£_{49} 90$ generated from job contracts and advertising. These sources constitute all the revenue of the printing office with the exclusion of that from book sales

9I For example, see the Toronto Mirror 14 Feb. I840, when the editor announced that he was agent for the Boston Pilot, an American paper "devoted to the defence and vindication of Irish character;" and the Banner 7 Feb. 1845, when the editor advertised that he was agent for the New York Albion, the Old Countryman, and Chambers Edinburgh Journal.

92 Globe 26 Mar. 1844 and Toronto Herald 7 Oct. 1839.

93 Observer 16 Oct. 1820.

94 Ian Dalton, "Dalton, Thomas," in Dictionary of Canadian Biography, VII, 22823I. Dalton won a Frontenac seat in I825. David Ouellette, "Scobie, Hugh," in Dictionary of Canadian Biography, VIII, 789-791. Scobie was elected magistrate in Toronto in 1842 and was appointed to the Board of Education in 1846 but lost the seat in a riding of York to Baldwin in 1847-48. Stanton to Lord Sydenham Io July I84I, Robert Stanton Narrative Memoranda. For an interesting discussion on the large number of printers who were also parliamentarians in Lower Canada see Gilles Gallichan, Livre et politique au Bas-Canada, I791-I849 (Sillery: Les Editions Septentrion, 199I). 
which was credited to the book room. The total income amounts to £1239. If one assumes that the total expenses of £9II cited in I830 remained approximately the same in 1835 , the office would have netted a profit of $\mathfrak{£}_{328}$.

Since the Christian Guardian had a very large circulation, for the second scenario I will calculate the typical income generated from the various sources cited above, as I did for the calculation of typical expenses. The typical income from the sources on government advertising approximated $£_{25} 5$ annually. Drawing from the Christian Guardian records in 1831 - the only documentation available private advertising generated approximately $£ 83$ annually. (I am assuming that all advertising clients paid their bills or they would not be able to advertise in the newspaper again.) From Mackenzie's evidence the typical income from provincial government printing contracts, excluding the huge contract for printing the Journal of the House of Assembly, totalled $£_{21}$ annually, and the typical income from contracts from the corporation of the city of Toronto was about $\mathfrak{E}_{70}$ annually. Finally I will assume that this typical shop received the $£_{75}$ payment for printing the debates of parliament. All of these sources totalled $£_{273}$. If the typical expenses as estimated above were $£_{747}$, this typical office would have had to generate $£ 474$ from subscription fees and private printing jobs to simply stay out debt. If half of its subscribers paid their fees, the circulation of this shop would have had to number about 950 subscribers in order for the office to generate this income. This number falls within the range of the circulation of a typical shop. ${ }^{95}$ Income from all job work would then have been a net gain, making the typical newspaper shop financially successful. ${ }^{96}$

It was hard work to earn a living from a newspaper shop. Many newspaper proprietors in the first half of the nineteenth century

$95 \mathrm{My}$ analysis has demonstrated that the average circulation for a large shop was between 1000 and 1300 newspapers and for a more moderately sized shop the circulation was between 750 and roso newspapers. See Juliana Stabile, "Toronto Newspapers, 1798-1845: A Case Study in Print Culture,” (Diss. U of Toronto, 2002), chapter 7 .

96 These estimates of expenses and revenue are calculated on incomplete evidence and based on assumptions that the average shop had approximately the expenses and the revenue documented by the few extant records available. However, this is the only surviving evidence. These calculations are intended to give some insight into the possible total expenses and the possible total revenues of a printing shop of the period to determine if a newspaper business was successful. 
experienced financial difficulties. Mackenzie complained of monetary problems during his entire newspaper career in Upper Canada. When Charles Donlevy, co-proprietor of the Toronto Mirror, died in 1858 , his estate was valued at $£_{400}$, not a significant sum. ${ }^{97}$ The Christian Guardian, a Toronto newspaper with the one of the highest circulation rates, suffered losses in some years: it lost $£_{12} 8$ in I830 and $\mathfrak{E}_{140} \mathrm{O}$ in $\mathrm{I} 84 \mathrm{I}$. On the other hand, its records noted a respectable profit in other years: it enjoyed profitable returns of $£_{265}$ in I834, $£_{220}$ in 1838 , and $£_{3} 82$ in $1847 .^{98}$

My rough calculations indicate that the typical shop probably had a profit in the years when it did not expend a large amount of money on major printing equipment. Moreover, although advertising was the largest source of newspaper income, the Christian Guardian had one of the smallest advertising sections of the period, and still showed a net gain in a number of years. One could logically conclude that newspapers such as the Toronto Patriot, the Toronto Herald and the British Colonist, which assigned as much as three-quarters of newspaper space to advertising, probably enjoyed a healthy annual profit. In fact, the proprietors of two of these newspapers left significant estates. At the time of his death in 1840 , the estate of Thomas Dalton, proprietor of the Toronto Patriot, was valued at $£$ I250, exclusive of the worth of the family home and the goodwill of the printing business. Although Scobie's financial success could be attributed to his highly diversified business, which included bookbinding, publishing, printing and lithographic services, as well as sales of books, in 1853 this proprietor of the British Colonist, left an estate worth the considerable sum of $£_{5000.99}$ In addition, the estates of Francis Collins, proprietor of the Canadian Freeman, and William Coates, independent printer and proprietor of the Toronto Star, also reflected financial success. In I834 the administrators of Collins' estate put up a bond for £rooo, an amount which must have approximated the value of the estate. At the time of his death

97 Court of Probate, Toronto (York), Estate Files 1793-1859, RG22, Series 305, Archives of Ontario. Other factors in Donlevy's life other than his newspaper business could have influenced the value of his estate; however, his newspaper business must have played a large role in the money or lack of it, which he accumulated in his life.

98 Reports of the Book and Printing Committee, 1829-1854, Appendix to Annual Conference Minutes, I824-1854.

99 Court of Probate, Toronto (York) Estate Files 1793-1859. 
in 1858 , William Coates left a large parcel of land on Queen Street, which brought the estate's total value to between $£_{4000}$ and $£ 8000$. ${ }^{\text {IOO }}$

Proprietors of successful newspapers, therefore, enjoyed some financial security. A careful examination of their newspaper businesses, if documentation were extant, would probably reveal the existence of the following factors necessary for financial success: a good circulation and a good subscription collection rate, a substantial amount of advertising, an effective distribution network, a number of government printing contracts in combination with other job printing accounts, patronage assignments, links with various social, cultural, financial groups and/or prominent people, and some other source(s) of income to supplement the printing business.

\section{SOMMAIRE}

Cet article décrit l'environnement financier d'un commerce de journaux au dix-neuvième siècle. Concentrée sur les commerces à Toronto la recherche a été effectuée de manière à montrer si une entreprise de journaux de cette époque pouvait être viable au plan financier. Les livres ou journaux comptables et les archives d'imprimerie des propriétaires de journaux à Toronto n'ayant pas survécu ou étant incomplets, le contexte économique d'un commerce de journaux a été reconstitué à partir d'archives éparpillées en ce qui a trait aux bureaux de Toronto et de renseignements tirés des journaux eux-mêmes. À partir de ces données l'auteur a créé un livre de compte hypothétique exposant à grands traits les dépenses et les sources de revenu d'un commerce. Au débit du journal comptable l'article examine les dépenses suivantes d'une année typique : polices de caractères et équipement d'impression - à la fois les dépenses initiales et l'équipement neuf ou de remplacement, les fournitures (le papier en particulier qui constituait la dépense la plus importante après les coûts de la main d'œuvre) - les frais de location et d'assurance, d'expédition par la poste et de main d'œuvre. Au crédit du journal comptable la discussion considère les sources possibles de revenu d'un commerce d'impression typique : les revenus provenant des abonnements et de la publicité, les contrats d'impression avec le gouvernement, les contrats avec l'entreprise privée, ainsi que des travaux supplémentaires reliés au métier d'imprimeur tels que l'édition

I0o Surrogate Court of Toronto (York), Estate Files I8II-I864, RG 22, Archives of Ontario. 
et la vente de livres. Bien que la plupart des propriétaires avaient beaucoup de difficultés à recueillir l'argent provenant des abonnements, cette étude en arrive à la conclusion qu' un commerce de journaux ayant un bon réseau de distribution pouvait en toute probabilité montrer un profit au cours des années où un montant d'argent important n'était pas dépensé pour de l'équipement. 
